\title{
ANALISIS USABILITAS PADA APLIKASI MOBILE TRIP PLANNER ETOURISM PARIWISATA DI BALI
}

\author{
Bagus Made Sabda Nirmala ${ }^{1}$, Made Liandana ${ }^{2}$ \\ 1 \\ Sistem Informasi, STIKOM Bali \\ Denpasar-Bali, Indonesia \\ ${ }^{2}$ Sistem Komputer, STIKOM Bali \\ Denpasar-Bali, Indonesia \\ e-mail: sabda@stikom-bali.ac.id ${ }^{1}$, liandana@stikom-bali.ac.id ${ }^{2}$
}

\begin{abstract}
Abstrak
Pariwisata merupakan salah satu sektor industri yang sangat berkembang di Bali. Masyarakat lokal seperti di desa Gobleg, desa Munduk, desa Sambangan, Desa Wanagiri dan desa lainnya di Bali mempertahankan cara alami dalam mengolah hasil alam mereka. Masyarakat lokal di desa ini, perlu mendapat perhatian lebih, dalam memperkenalkan sumber daya alam, sumber daya manusia serta kearifan lokal yang mereka miliki dalam industri pariwisata tanpa merusak tradisi yang sudah dimiliki desa tersebut. Saat ini masih kurang sarana untuk memperkenalkan kunjungan wisatawan domestik maupun mancanegara tentang potensi desa dan kearifan lokal di Bali. Kunjungan terhadap desa wisata jarang mendapat sentuhan promosi pariwisata pada umumnya. Kearifan lokal hingga desa wisata masih kurang memanfaatkan teknologi informasi serta media promosi yang efektif. Penelitian ini bertujuan untuk mengembangkan aplikasi mobile android Trip Planner, dalam bidang etourism yang dapat digunakan oleh wisatawan untuk mengetahui lokasi tempat wisata di sekitar desa wisata yang ada di Bali. Penelitian ini berfokus pada kebergunaan atau usabilitas dari aplikasi trip planner dengan mengukur aspek efficiency of use, learnability, satisfaction, memorability dan error frequency. Pengujian usabilitas ini digunakan untuk menunjukkan kemudahan user dalam menggunakan aplikasi ini. Pengujian dilakukan dengan memberikan pertanyaan terkait aspek usabilitas. Hasil pengujian menunjukkan nilai 3,73 dari skala 5 dalam hal kemudahan user mengingat kembali tampilan dan menu aplikasi ini yang mencakup aspek memorability dan satisfaction.
\end{abstract}

Kata kunci: android, etourism, efficiency of use, usabilitias

\section{PENDAHULUAN}

Pariwisata merupakan sektor industri yang besar di dunia, begitu juga di Bali. Pengaruh teknologi terutama internet, membawa dunia pariwisata ke ranah digital yang biasa disebut sebagai e-tourism. etourism merupakan segala upaya digitalisasi dari proses bisnis, value chain dan informasi di bidang pariwisata [1]. eTourism yang sering diimplementasikan dapat berupa reservasi online hotel, reservasi online akomodasi, platform informasi Point of Interest (Pol), dan travel video blog. eTourism berperan penting dalam meningkatkan perkembangan sektor pariwisata konvensional, seperti kunjungan
Pol (pantai, gunung dan air terjun), restoran, hotel dan kearifan lokal yang mampu menjadi daya tarik wisata.

Perkembangan etourism di Bali tidak tanpa tantangan. Pariwisata di Bali masih terkendala pemanfaatan teknologi mobile secara efektif. Penggunaan teknologi mobile yang biasanya berupa aplikasi masih memerlukan porsi lebih untuk membantu perkembangan pariwisata di Bali. Aplikasi yang sudah berkembang saat ini lebih banyak berfokus pada $e$ commerce, reservasi online hotel dan akomodasi. Aplikasi ini tidak menyentuh langsung komponen masyarakat lokal yang membutuhkan cara yang lebih efektif untuk 
memperkenalkan desa mereka melalui dunia digital dan mampu meningkatkan perekonomian melalui sektor pariwisata.

Pariwisata desa wisata dan kearifan lokal menjadi salah satu contoh kurangnya pemanfaatan aplikasi mobile, karena masih sedikit sekali perangkat yang menekankan informasi serta perencana perjalanan khususnya desa wisata dan kearifan lokal. Lima tahun terakhir, desa wisata sudah mulai dikembangkan di Bali. Desa wisata merupakan salah satu bentuk pariwisata dengan memanfaatkan kekayaan alam yang sudah ada dan mengintegrasikan antara alam, kegiatan masyarakat lokal dan akomodasi hingga menjadi daerah kunjungan wisata. Biasanya masyarakat memilliki budaya yang masih asri. Selain itu desa wisata biasanya memiliki makanan khas hingga tata sosial yang khusus dibandingkan desa lainnya. Wisata kearifan lokal sendiri biasanya berwujud kesenian atau tradisi yang berakar pada kebudayaan turun temurun. Kearifan lokal ini menjadi salah satu bagian untuk menarik wisatawan untuk datang. Desa yang berada di daerah Buleleng merupakan desa yang tidak terlalu banyak mendapatkan porsi promosi dibandingkan wilayah Bali selatan dan kabupaten Gianyar. Karena itu dirasa perlu adanya aplikasi yang mampu mendukung pengenalan desa wisata seperti desa Gobleg, Sambangan dan desa Munduk.

Lima tahun ini telah dilakukan upaya pemanfaatan teknologi mobile untuk mendukung e-tourism. Penelitian ini berfokus untuk perencanaan perjalanan atau trip planner. Pada penelitian yang telah dilakukan[2] membahas tentang aplikasi perencanaan perjalanan dan rekomendasi tempat pariwisata. Penelitian ini menekankan kemampuan aplikasi dalam merekomendasikan tempat pariwisata berdasarkan karakteristik user. Penelitian ini mempelajari perilaku user terhadap penggunaan aplikasi, klasifikasi demografi user, termasuk tempat yang sudah pernah dikunjungi menggunakan aplikasi tersebut. Selanjutnya aplikasi menghasilkan rekomendasi berdasarkan hal tersebut.

Penelitian yang telah dilakukan pada tahun 2003 [3] membahas tentang pengembangan aplikasi e-tourism dengan menggunakan metode reasoning. Metode ini merupakan bagian dari Artificial Intelligence. Teknik yang digunakan adalah CBR techniques. Teknik ini membantu dalam menemukan saran terbaik dalam menghasilkan itinerary yang paling sesuai karakteristik user. Penelitian lain yang telah dilakukan juga di ITMO University[4] membahas pengembangan aplikasi mobile tourist guide. Penelitian ini membahas aplikasi mobile yang mampu memberikan rekomendasi tujuan wisata berdasarkan preferensi user dan situasi tempat tujuan tersebut. Atraksi dan tujuan wisata ini digali dari internet misalnya Wikipedia, Wikivoyage, dan Panoramio. Rekomendasi yang dihasilkan berdasarkan rating yang dihasilkan oleh aplikasi ini. Rating ini berdasarkan service-based application yang memanfaatkan dukungan berupa interoperabilitas ontologi dan semantik. Penelitian lain yang dilakukan pada tahun 2015 berbasis google maps bertujuan untuk pengembangan platform travel planning berdasarkan peta digital[5]. Penelitian ini menjelaskan bahwa di Taiwan, adanya peningkatan kebutuhan trip self-planning. User lebih menyukai dalam pembuatan jadwal perjalanan secara mandiri.

Aplikasi mobile berbasis android yang dikembangkan ini diharapkan mampu memberikan informasi tentang desa wisata dan kearifan lokal. Aplikasi ini juga mampu menghasilkan itinerary yang dibuat oleh wisatawan sendiri. Aplikasi ini berfokus pada kebergunaan atau usabilitas dari aplikasi tripplanner dengan mengukur aspek efficiency of use, intuitive design, learnability, satisfaction, memorability dan error frequency. Kelebihan Aplikasi yang dikembangkan ini, mampu mempromosikan masyarakat lokal sebagai pemandu lokal sehingga kearifan lokal mampu dijaga dengan memberdayakan masyarakat asli desa tersebut sebagai pemandunya. Sehingga meningkatkan nilai manfaat bagi masyarakat di desa tersebut baik secara ekonomi maupun sosial. Penelitian ini berfokus pada usabilitas aplikasi mobile Trip planner yang dibuat. Penggunaan aplikasi ini akan diteliti untuk mengetahui 
seberapa mudah user menggunakan aplikasi ini, sehingga dengan penelitian ini dapat diperoleh desain User Interface (UI) yang efektif dan dengan meningkatkan UI berdasar user experience diharapkan aplikasi ini mampu membantu mendukung pariwisata untuk desa wisata dan kearifan lokal di Bali.

\section{LANDASAN TEORI eTourism}

eTourism merupakan upaya dalam meningkatkan segala hal dalam industri pariwisata ke bentuk digital. e-tourism merupakan adaptasi bentuk dunia pariwisata karena pengaruh berkembangnya Information and Communicatin Technology (ICT). Menurut Buhalis [1], e-tourism disebut sebagai refleksi digitalisasi semua proses, value chain dalam pariwisata, travel dan hospitality industry yang bisa mencakup bidang e-commerce dan teknik yang digunakan untuk meningkatkan efisiensi dan efektivitas suatu organisasi di bidang pariwisata. Pada level strategis, e-tourism mampu merevolusi proses bisnis dari suatu usaha dengan pemanfaatan ICT yang sudah ada. Konsep e-tourism meliputi semua fungsi bisnis terkait yang memanfaatkan teknologi misalnya $e-$ commerce, e-marketing, e-finance, eproduction, e-strategy dan development product.

\section{Desa Wisata dan Kearifan Lokal}

Kearifan lokal yang digunakan oleh masyarakat sebagai rambu-rambu atau pedoman dalam menjalani kehidupannya. Menurut penelitian sebelumnya (Yunus 2014) kearifan lokal adalah "merupakan bagian dari sebuah skema dari tingkatan budaya (hierarki bukan berdasarkan baik dan buruk)." Judistira juga mengungkapkan bahwa kebudayaan lokal berfungsi untuk melengkapi kebudayaan regional, dan kebudayaan regional adalah bagian-bagian yang hakiki dalam bentukan kebudayaan nasional. Menurut Yunus (2014) pengaruh globalisasi yang mewarnai seluruh aktivitas masyarakat perlu disikapi dengan bijak sehingga pengaruh globalisasi tersebut dapat dimanfaatkan secara baik. Lebih jauh lagi Yunus mengungkapkan bahwa kemampuan bangsa dituntut untuk dapat beradaptasi dengan perkembangan zaman tanpa mengabaikan nilai-nilai kearifan lokal sebagai kekuatan identitas bangsa.

\section{Usabilitas}

Usabilitas atau kebergunaan mengacu pada kemudahan manusia untuk menggunakan suatu alat atau produk tertentu. Dalam interaksi manusia komputer dan ilmu komputer, kebergunaan merujuk pada kejelasan interaksi dengan hasil rancangan suatu perangkat lunak. Usabilitas merupakan analisis kualitatif suatu produk, dengan memperhatikan seberapa mudah user menggunakan interface produk tersebut [7]. Suatu Aplikasi atau produk disebut mudah digunakan (usable) jika fungsi yang terdapat pada aplikasi ini dapat dijalankan secara efektif dan efisien selain itu juga memuaskan bagi user. Pengujian usabilitas diharapkan mampu mengurangi permintaan perubahan desain produk oleh user atau client, tugas yang terlalu banyak (overlooked tasks) dan ketidakpahaman user terhadap kebutuhan mereka dari produk yang dikembangkan [8].

Usabilitas dapat diukur dari beberapa aspek seperti learnability, efficiency, memorability, errors, dan satisfaction [9]. Learnability berkaitan dengan tingkat kemudahan user untuk memenuhi tugas-tugas dasar ketika pertama kali user melihat atau menggunakan suatu desain perangkat lunak. Efficiency menjelaskan tingkat kecepatan user dalam menyelesaikan tugas-tugas setelah user mempelajari rancangan perangkat lunak. Memorability menjelaskan tingkat kemudahan user dalam menggunakan rancangan dengan baik, setelah beberapa lama tidak menggunakannya. Errors menjelaskan jumlah kesalahan yang dilakukan oleh user. Satisfaction berkaitan dengan tingkat kepuasan user dalam menggunakan suatu rancangan perangkat lunak.

$\begin{array}{cr}\text { Pengujian usabilitas } & \text { diantaranya } \\ \text { adalah metode kuisioner, } & \text { metode }\end{array}$


observasi langsung dan thinking Aloud [10]. Pada metode observasi, seorang observator akan melakukan observasi secara langsung terhadap satu atau lebih user produk yang diuji. Metode kuisioner dilakukan dengan memberikan beberapa pertanyaan kepada user atau responden terkait penggunaan produk yang diuji, Metode thinking aloud dilakukan dengan mengamati secara terus menerus sikap tubuh dan ucapan yang ditunjukkan oleh responden saat mencoba produk yang diuji. Penggunaan metode pengujian kembali lagi dengan kebutuhan, efisiensi dan efektivitas dari tujian pengujian produk itu sendiri.

\section{DESAIN SISTEM \\ Arsitektur Sistem}

Arsitektur sistem untuk aplikasi Trip Planner ditunjukkan pada Gambar 5.1. Wisatawan dan Guide dapat mengakses sistem ini melalui aplikasi mobile. Wisatawan dapat melihat tujuan wisata yang dapat dikunjungi, memilih tujuan wisata, dan memilih Guide yang akan memandu selama perjalanan. Sedangkan Guide dapat melihat wisatawan yang sudah memlihnya sebagai pemandu selama melakukan perjalanan. Web admin bertugas untuk melakukan pengelolaan data, seperti: data Guide, data Wisatawan, dan data tujuan wisata, data-data tersebut disimpan di dalam basis data.

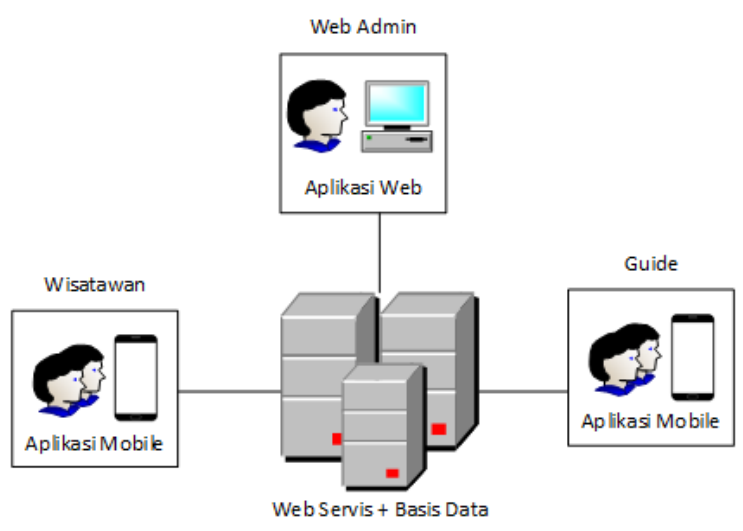

Gambar 1. Arsitektur Sistem

\section{Diagram Use Case}

Setiap Fungsi yang dimiliki oleh sistem trip planner dimodelkan dengan menggunakan diagram use case. Terdapat tiga aktor yang terlibat pada aplikasi yang dikembangkan, yaitu Wisatawan, Guide, dan Web Admin. Fungsi-fungsi yang dimiliki oleh sistem meliputi Register Account, Menampilkan Daftar Destinasi, Membuat Rencana Perjalanan, Mengelola Data Destinasi, Mengelola Data Guide, dan Mengelola Data Wisatawan. Fungsi-fungsi tersebut didefinisikan kedalam tujuh buah usecase. Register Account berfungsi untuk memberikan fasilitas untuk melakukan registrasi bagi Wisatawan yang akan menggunakan aplikasi ini. Wisatawan akan disuguhkan beberapa destinasi wisata melalui fungsi Menampilkan Daftar Destinasi. Wisatawan dapat membuat rencana perjalanan melalui fungsi Membuat Rencana Perjalanan Wisata.
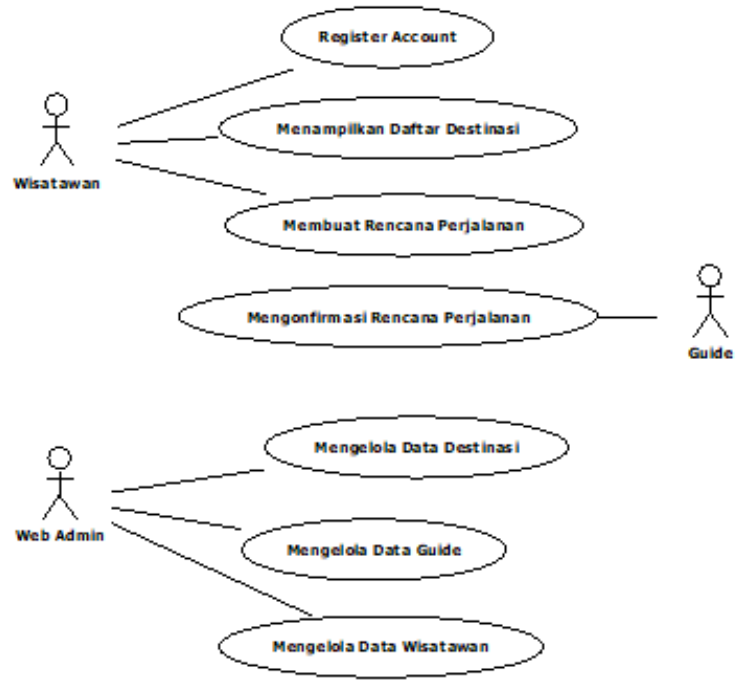

Gambar 2. Diagram Use Case Aplikasi Trip Planner 




Gambar 3. Diagram Class Sistem Trip Planner

Guide dapat menggunakan aplikasi ini melalui fungsi Mengonfirmasi Rencana Perjalanan, fungsi ini disediakan agar guide dapat mengonfirmasi setiap wisatawan yang akan dipandu sesuai dengan rencana perjalan yang sudah dibuat oleh wisatawan. Mengelola Data Destinasi, Mengelola Data Guide, dan Mengelola Data Wisatawan merupakan fungsi yang disediakan untuk Web Admin, fungsi ini digunakan untuk menambah, mengedit, dan menghapus data wisatawan.

\section{Diagram Class}

Class digunakan untuk mendefinisikan objek-objek yang terlibat dalam sistem. Pada Aplikasi ini terdapat 11 diagram class yang terlibat, yaitu class Main, Wisatawan, Guide, Destinasi, Trip, API, WebService, WebDestinasi, WebWisatawan, WebGuide, dan WebTrip. Untuk class WebService, WebDestinasi, WebWisatawan, WebGuide, dan WebTrip merupakan class yang terdapat pada aplikasi berbasis web, sedangkan untuk class-class yang lainnya terdapat pada aplikasi mobile. Diagram class ditunjukkan pada Gambar 3.

\section{Desain Database}

Gambar 4 menunjukkan konseptual database dan relasinya antar entitas. Terdapat lima entitas yang terlibat yaitu: Destinasi, ObjekWisata, TripPlan, Guide, dan Wisatawan. Untuk struktur tabel ditunjukan pada Tabel 1 sampai dengan 5 


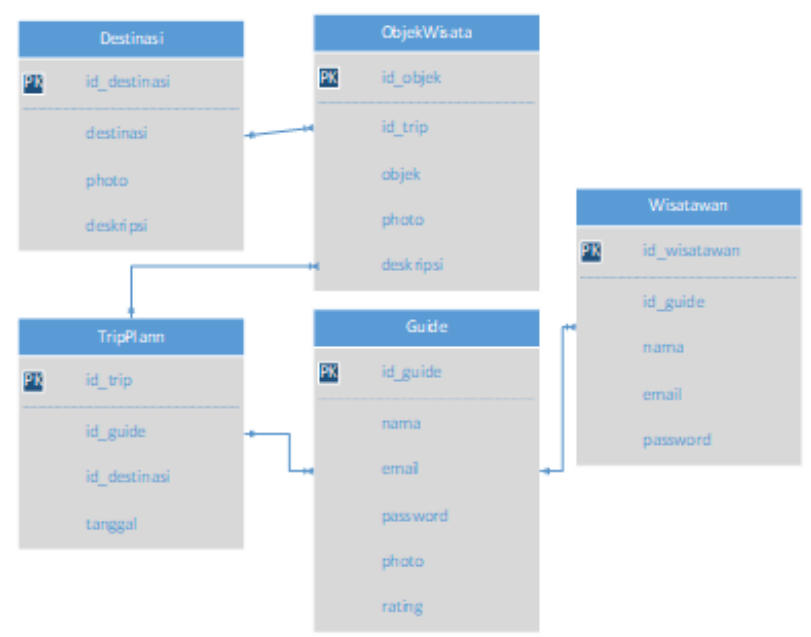

Gambar 4 Konseptual Database 
Tabel 1. Tabel Destinasi

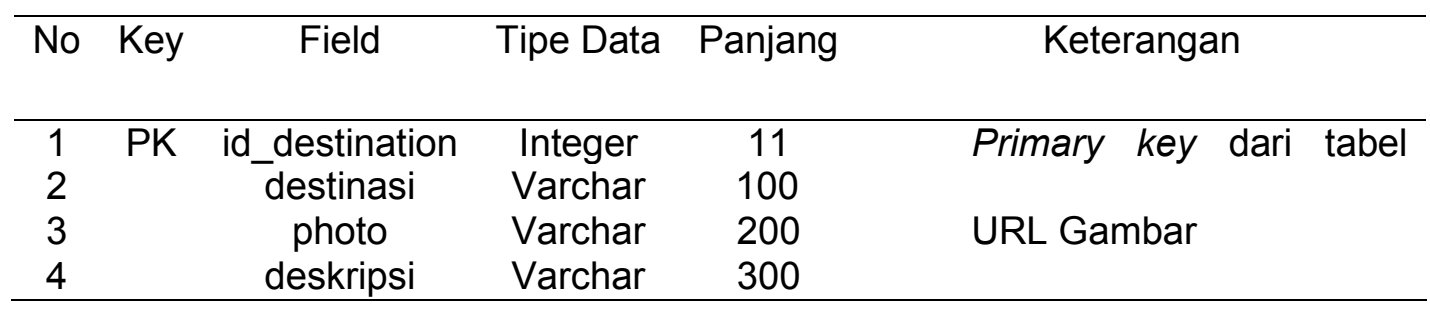

Tabel 2. Tabel Trip

\begin{tabular}{cccccl}
\hline No & Key & Field & Tipe Data & Panjang & Keterangan \\
& & & & & \\
\hline 1 & PK & id_destination & Integer & 11 & Primary key dari tabel trip \\
2 & FK & id_destination & Integer & 11 & Foreign Key dari tabel \\
3 & FK & id_guide & Integer & 11 & Foreign Key dari tabel guide \\
4 & & tanggal & Date & & Tanggal rencana perjalanan \\
\hline
\end{tabular}

Tabel 3. Tabel Objek Wisata

\begin{tabular}{cccccc}
\hline No & Key & Field & Tipe Data & Panjang & Keterangan \\
& & & & & \\
\hline 1 & PK & id_objek & Integer & 11 & Primary key dari tabel objek \\
2 & FK & id_trip & Integer & 11 & Foreign Key dari tabel trip \\
3 & & objek & Varchar & 200 & \\
4 & & photo & Varchar & 200 & URL Gambar \\
5 & & despriksi & Varchar & 300 & \\
\hline
\end{tabular}

Tabel 4. Table Guide

\begin{tabular}{cccccccc}
\hline No & Key & Field & Tipe Data & Panjang & & Keterangan & \\
& & & & & & & \\
\hline 1 & PK & id_objek & Integer & 11 & Primary & key & dari tabel \\
2 & & nama & Varchar & 100 & & & \\
3 & & email & Varchar & 75 & & & \\
4 & & password & Varchar & 100 & & & \\
5 & & photo & Varchar & 200 & & & \\
6 & & despriksi & Varchar & 300 & & & \\
\hline
\end{tabular}

Tabel 5. Table Wistawan

\begin{tabular}{cccccl}
\hline No & Key & Field & Tipe Data & Panjang & Keterangan \\
& & & & & \\
\hline 1 & PK & id_wisatawan & Integer & 11 & Primary key dari tabel Wisatawan \\
2 & FK & id_guide & Integer & 11 & Forein Key dari tabel guide \\
3 & & nama & Varchar & 200 & \\
4 & & email & Varchar & 75 & \\
5 & & password & Varchar & 100 & \\
\hline
\end{tabular}




\section{PENGUJIAN USABILITAS}

Pengujian usabilitas sering juga disebut sebagai acceptance testing. Pengujian yang mengukur nilai penerimaan dan pemahaman user terhadap suatu produk yang diuji[11]. Pengukuran ini berdasarkan ketepatan dan keberhasilan user dalam mengoperasikan produk yang diuji berdasarkan task yang diberikan. Tujuan pengujian usabilitas ini untuk mengetahui efektivitas dari desain produk yang diuji yaitu aplikasi tripplanner. Pengujian yang dilakukan ini berdasarkan aspek-aspek usabilitas seperti efficiency of use, intuitive design, learnability, satisfaction, memorability dan error frequency.

Metode pengujian usabilitas yang digunakan dalam penelitian ini adalah metode kuisioner dengan respon user dari berbgai usia. Jumlah responder yang digunakan berjumlah 30 orang. Pada pengujian ini responden terlebih dahulu diberikan pertanyaan dan tercatat bahwa responden mengerti aplikasi pada perangkat mobile tetapi belum pernah menggunakan aplikasi yang diuji sebelumnya. Pengujian dilakukan dengan menggunakan alat-alat berupa smartphone, selembar task dan alat tulis. Task pengujian usabilitas yang diberikan kepada user adalah sebagai berikut:

1. Lakukan login sebagai user dalam aplikasi android ini

2. Cari dalam aplikasi ini halaman home, explore, destination dan attraction

3. Lakukan Tambah attraction ke itinerary

4. Cari halaman itinerary yang telah dibuat

5. Lakukan logout untuk meninggalkan aplikasi trip planner dan lakukan login kembali.
Task pertama adalah meminta user login sebagai ke aplikasi android tripplanner. Task ini dimulai pada halaman depan aplikasi dengan mengisi form login berupa username dan password. Selanjutnya dilakukan klik tombol login. Selanjutnya task kedua meminta user untuk mencari menu attraction/destination dalam aplikasi tripplanner. Task kedua ini dapat dikatakan selesai ketika user telah dapat melihat informasi yang ada pada menu attraction/destination. Task ketiga, yaitu menambahkan attraction. Task ketiga ini meminta user untuk menambahkan beberapa attraction/destination yang ada pada menu attraction. Task ini dapat dikatakan selesai ketika user dapat menambahkan attraction/destination. Task keempat ini meminta user untuk melakukan pencarian halaman itinerary yang telah dibuat sebelumnya. Task keempat ini meminta user untuk membuka menu itinerary yang telah dibuat sebelumnya dengan menambahkan attraction. Task ini dapat dikatakan selesai ketika user dapat menampilkan itinerary yang telah dibuat. Task selanjutnya yaitu task kelima yang meminta user untuk melakukan logout untuk meninggalkan aplikasi tripplanner yang diuji. Task ini dilakukan oleh user untuk mencari tombol logout dan menekan tombol tersebut. Task ini dapat dikatakan selesai ketika user keluar dari aplikasi ini.

Setelah task selesai dilakukan oleh responden, tahap selanjutnya adalah memberikan pertanyaan dalam bentuk kuisioner. Tiap pertanyaan yang diberikan kepada responden bertujuan untuk menunjukkan tingkat usabilitas atau penerimaan user berdasarkan aspek-aspek usability testing. Pertanyaan yang diberikan dalam kuisioner dapat dilihat pada tabel 6 . 
beberapa lama tidak

Tabel 6. Pertanyaan Kuisioner

\begin{tabular}{ll}
\hline No & Pertanyaan \\
\hline 1 & $\begin{array}{l}\text { Apakah aplikasi dapat dikenal dengan baik sebagai } \\
\text { aplikasi perencana trip (tripplanner) }\end{array}$ \\
2 & $\begin{array}{l}\text { Apakah anda dengan mudah melakukan login? } \\
\text { Apakah anda dengan mudah menggunakan aplikasi } \\
\text { tripplanner ini dan mengakses menu home, explore } \\
\text { dan find attraction }\end{array}$ \\
4 & $\begin{array}{l}\text { Apakah anda mampu menambah attraction dengan } \\
\text { mudah? }\end{array}$ \\
5 & $\begin{array}{l}\text { Apakah anda mampu mencari halaman itinerary } \\
\text { dengan mudah? }\end{array}$ \\
6 & $\begin{array}{l}\text { Apakah anda dapat mengakses informasi pada } \\
\text { setiap menu? }\end{array}$ \\
7 & $\begin{array}{l}\text { Apakah huruf yang ada mudah dibaca? } \\
\text { Apakah simbol atau icon yang terdapat pada } \\
\text { aplikasi mudah dipahami? } \\
\text { Apakah desain warna pada aplikasi ini nyaman jika } \\
\text { digunakan dalam waktu lama? } \\
\text { Apakah bahasa yang ditampilkan mudah } \\
11\end{array} \quad \begin{array}{l}\text { Lakukan logout. Setelah itu apakah mudah untuk } \\
\text { melakukan login kembali? } \\
\text { Apakah anda dapat mengingat kembali menu- } \\
\text { menu dan tampilan tiap menu pada aplikasi ini? }\end{array}$ \\
\hline
\end{tabular}

Pada tabel 6 ini, diurutkan pertanyaan yang digunakan user untuk melakukan pengujian pada produk aplikasi tripplanner ini. Semua pertanyaan ini mewakili aspekaspek dari usabilitas. Lima Aspek usabilitas ini adalah:

1. Learnability berkaitan dengan tingkat kemudahan user untuk memenuhi tugas-tugas dasar ketika pertama kali user melihat atau menggunakan produk yang diuji.

2. Efficiency menjelaskan tingkat kecepatan user dalam menyelesaikan tugas-tugas setelah user mempelajari suatu produk.

3. Memorability menjelaskan tingkat kemudahan user dalam menggunakan dan mengingat fitur suatu produk dengan baik, setelah menggunakannya.

4. Errors menjelaskan jumlah kesalahan yang dilakukan oleh user dalam mengoperasikan produk yang diuji.

5. Satisfaction berkaitan dengan tingkat kepuasan user dalam menggunakan suatu produk yang telah diuji.

Masing-masing pertanyaan pada tabel 6 memiliki kontribusi terhadap masing-masing aspek usabilitas, baik itu learnabilitym efficiency, memorability, errors dan satisfaction. Pada tabel 7 ditunjukkan plot setiap pertanyaan terhadap aspek usabilitas. 
Tabel 7. Plot Pertanyaan terhadap aspek usabilitas

\begin{tabular}{|c|c|c|c|c|c|c|}
\hline \multirow[b]{2}{*}{ No } & \multirow[b]{2}{*}{ Pertanyaan } & \multicolumn{5}{|c|}{ Aspek } \\
\hline & & Learn & Effic & Memo & Errors & Sattsf \\
\hline 1 & $\begin{array}{l}\text { Apakah aplikasi dapat dikenal dengan baik } \\
\text { sebagai aplikasi perencana trip (tripplanner) }\end{array}$ & & & & & \\
\hline 2 & Apakah anda dengan mudah melakukan login? & & & & & \\
\hline 3 & $\begin{array}{l}\text { Apakah anda dengan mudah menggunakan } \\
\text { aplikasi tripplanner ini dan mengakses menu } \\
\text { home, explore dan attraction }\end{array}$ & & & & & \\
\hline 4 & $\begin{array}{l}\text { Apakah anda mampu menambah attraction } \\
\text { dengan mudah? }\end{array}$ & & & & & \\
\hline 5 & $\begin{array}{l}\text { Apakah anda mampu mencari halaman } \\
\text { itinerary dengan mudah? }\end{array}$ & & & & & \\
\hline 6 & $\begin{array}{l}\text { Apakah anda dapat mengakses informasi pada } \\
\text { setiap menu? }\end{array}$ & & & & & \\
\hline 7 & Apakah huruf yang ada mudah dibaca? & & & & & \\
\hline 8 & $\begin{array}{l}\text { Apakah simbol atau icon yang terdapat pada } \\
\text { aplikasi mudah dipahami? }\end{array}$ & & & & & \\
\hline 9 & $\begin{array}{l}\text { Apakah desain warna pada aplikasi ini nyaman } \\
\text { jika digunakan dalam waktu lama? }\end{array}$ & & & & & \\
\hline 10 & $\begin{array}{l}\text { Apakah bahasa yang ditampilkan mudah } \\
\text { dimengerti }\end{array}$ & & & & & \\
\hline 11 & $\begin{array}{l}\text { Lakukan logout. Setelah itu apakah mudah } \\
\text { untuk melakukan login kembali? }\end{array}$ & & & & & \\
\hline 12 & $\begin{array}{l}\text { Apakah anda dapat mengingat kembali menu- } \\
\text { menu dan tampilan tiap menu pada aplikasi ini? }\end{array}$ & & & & & \\
\hline
\end{tabular}

Pada tabel 7, semua pertanyaan yang digunakan dapat mencakup aspek-aspek dalam pengujian usabilitas pada sebuah produk. Setiap pertanyaan yang diajukan dapat mewakili lebih dari satu aspek usabilitas. Selain itu pertanyaan ketiga dan keenam dapat mencakup 5 aspek usabilitas ini. Setiap pertanyaan ini akan diujikan terhadap user. Pengujian ini menghasilkan grafik yang menyajikan perbandingan usabilitas dari tiap pertanyaan yang diajukan.

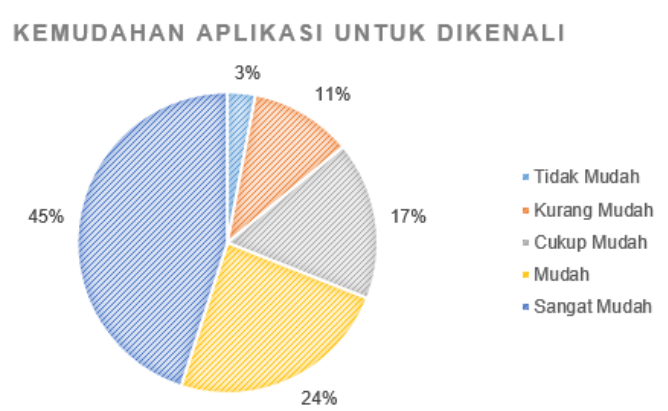

Gambar 5. Grafik Kemudahan Aplikasi untuk dikenali 
KEMUDAHAN LOGIN KE APLIKASI

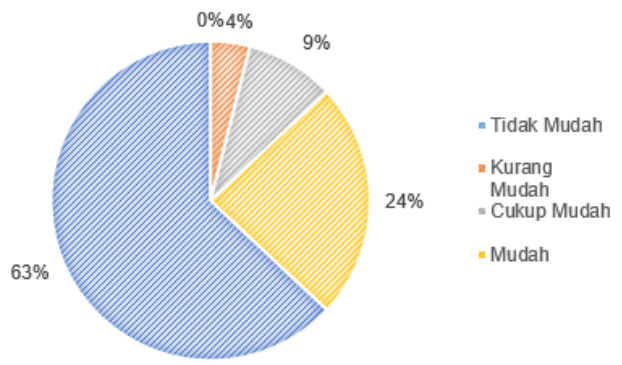

Gambar 6. Grafik kemudahan Login ke Aplikasi

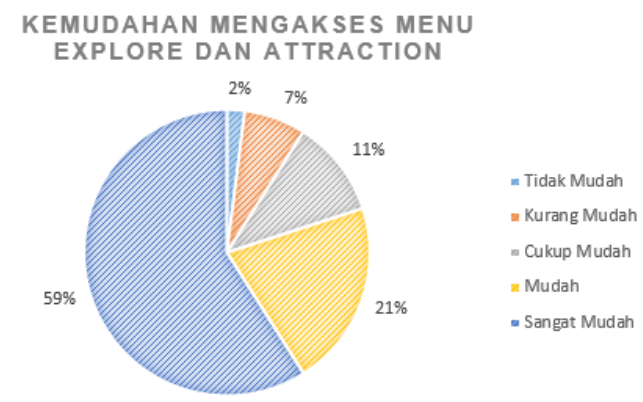

Gambar 7. Grafik Kemudahan Mengakses Explore dan Attraction

KEMUDAHAN MENAMBAHKAN
ATTRACTION PADA APLIKASI

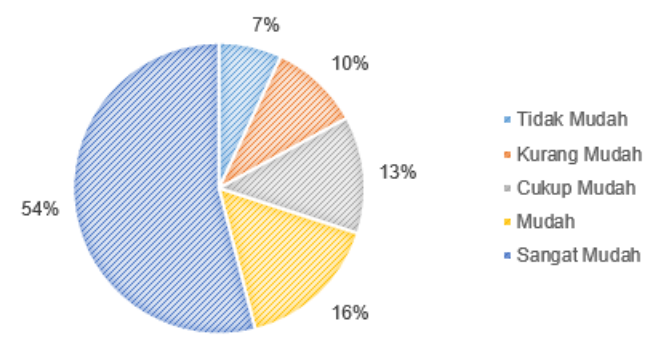

Gambar 8. Grafik Kemudahan Menambahkan Attraction

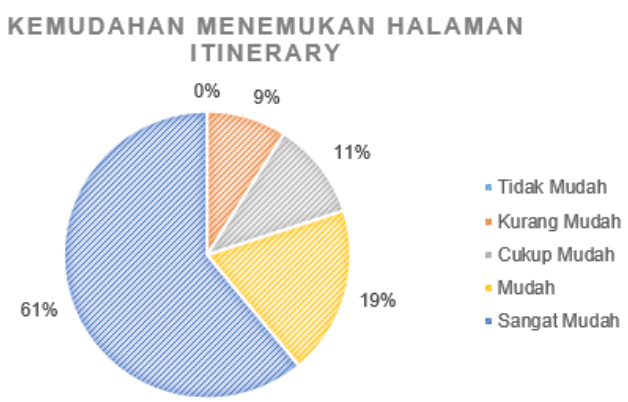

Gambar 9. Grafik Kemudahan Menemukan Halaman Itinerary

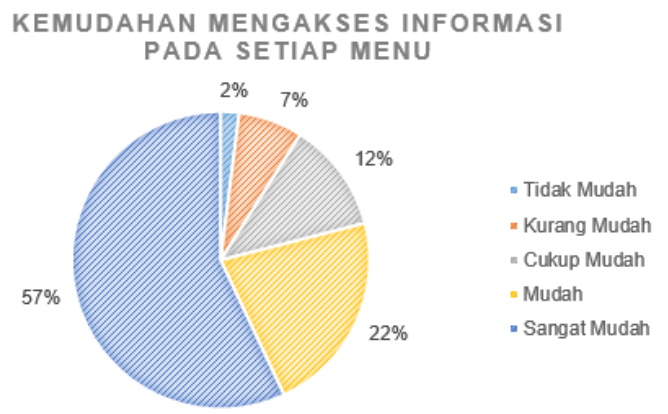

Gambar 10. Grafik kemudahan Mengakses Informasi pada Setiap Menu

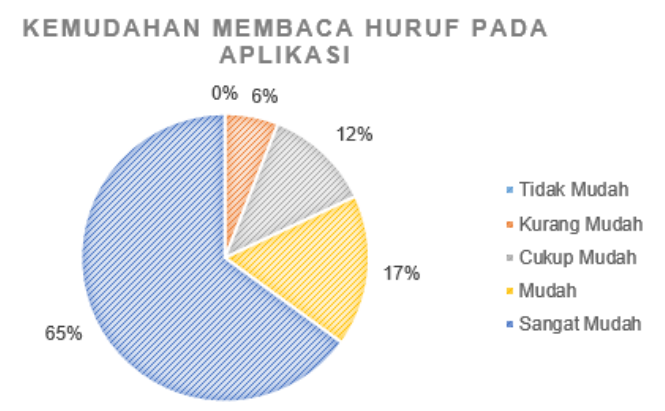

Gambar 11. Grafik kemudahan Membaca Huruf

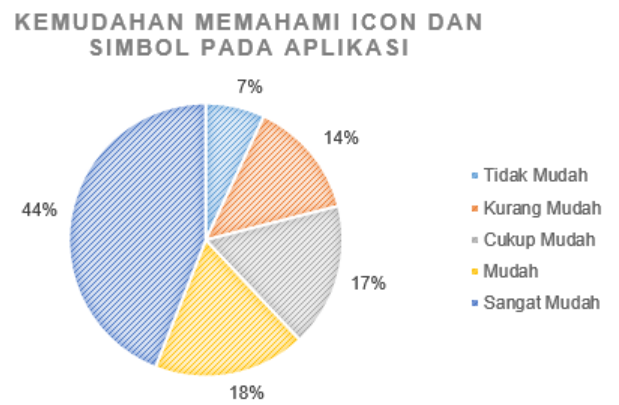

Gambar 12. Grafik Kemudahan Memahami Icon

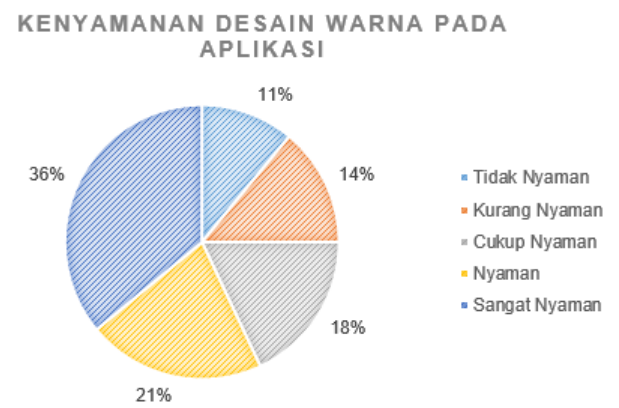

Gambar 13. Grafik Kenyamanan Desain Warna 


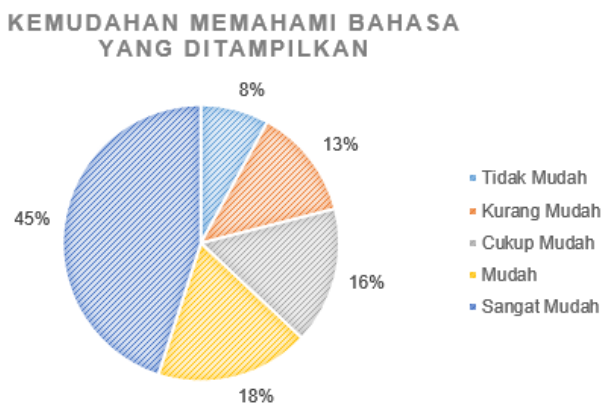

Gambar 14. Grafik memahami Bahasa

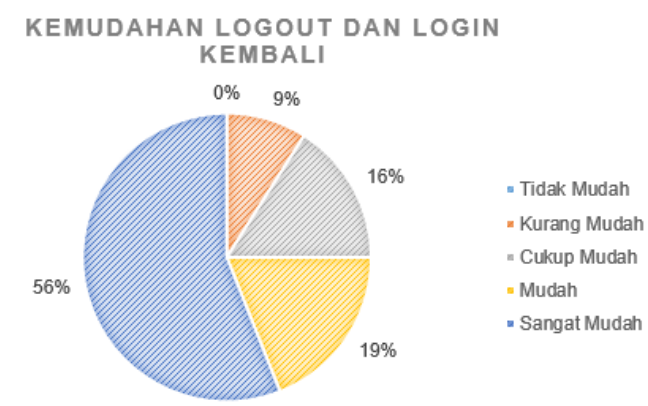

Gambar 15. Grafik Kemudahan Logout dan Login Kembali



Gambar 16. Grafik Mengingat Menu

Gambar 5 hingga 16 menunjukkan grafik perbandingan dari tiap pertanyaan terhadap pengujian user. Tiap Grafik ini menunjukkan seberapa mudah user menggunakan dan memahami aplikasi yang diuji. Pada Gambar 13 ditunjukkan nilai 36\% (sangat mudah) yang merupakan persentase terendah dari grafik yang dihasilkan. Hal ini menunjukkan dibandingkan pertanyaan yang lain, desain warna memperoleh nilai terendah untuk opsi jawaban "sangat mudah". Pada Gambar 12 diperoleh nilai $44 \%$ untuk opsi jawaban sangat mudah. Hal ini menunjukkan pemahaman terhadap icon memiliki nilai kedua terendah dibandingkan pertanyaan yang lain. Sedangkan pada
Gambar 8 diperoleh 54\% user menyatakan sangat mudah menambahkan attraction pada aplikasi yang diuji. Gambar 9 menunjukkan $61 \%$ user mudah menemukan halaman itinerary. Dari hasil pengujian usabilitas ini, diperoleh rekap nilai dari setiap pertanyaan yang diajukan terhadap aspek usabilitas yang ada. Rekap nilai dapat dilihat pada tabel 8 .

Tabel 8. Rekap Nilai Usabilitas

\begin{tabular}{|c|c|c|}
\hline No & Pertanyaan & Nilai \\
\hline 1 & Kemudahan aplikasi dikenali & 3,97 \\
\hline 2 & lahan login aplikasi & 4,40 \\
\hline 3 & han akses attraction & 4,28 \\
\hline 4 & $\begin{array}{l}\text { Kemudahan } \\
\text { attraction }\end{array}$ & 4,00 \\
\hline 5 & $\begin{array}{l}\text { ahan menemukan } \\
\text { ר itinerary }\end{array}$ & 32 \\
\hline 6 & $\begin{array}{l}\text { Kemudahan mengakses } \\
\text { informasi setiap menu }\end{array}$ & 4,25 \\
\hline 7 & Kem & 4,41 \\
\hline 8 & Ker & 3,78 \\
\hline 9 & Ker & 3,57 \\
\hline 10 & Ker & 3,79 \\
\hline 11 & $\begin{array}{l}\text { dahan logout dan login } \\
\text { li }\end{array}$ & 4,22 \\
\hline 12 & $\begin{array}{l}\text { Kemudahan } \\
\text { menu }\end{array}$ & 3,73 \\
\hline
\end{tabular}

Tabel 8 menunjukkan nilai kepuasan dari masing-masing pertanyaan yang diajukan kepada responden. Setiap pertanyaan menunjukkan nilai beragam, hal ini menunjukkan tingkat kepuasan user dari tiap pertanyaan adalah beragam. Nilai ini menggunakan rentang skala 1 hingga 5 seperti pada tabel 6 .

Secara keseluruhan nilai yang diperoleh sudah cukup baik dan telah mewakili aspek learnability, efficiency, memorability, errors dan satisfaction. Pada tabel 8 untuk pertanyaan 9 terkait desain warna diperoleh nilai 3,57 . Nilai ini cukup baik karena telah berada diatas nilai tengah 3. Dalam hal ini, dapat dikatakan desain warna sudah cukup baik. Pada Pertanyaan 2 diperoleh nilai 4,46 dari skala 5. Hal ini menunjukkan tidak adanya kesulitan dalam melakukan login pada aplikasi ini. Kemudahan aplikasi untuk dikenali mendapatkan nilai 3,97 dari skala 5. Hal ini menunjukkan pertanyaan ini telah 
mewakili aspek learnability dan satisfaction. Pertanyaan 3 dan pertanyaan 6 terkait kemudahan akses menu pada aplikasi ini diperoleh nilai 4,28 dan 4,25 dari skala 5 . Nilai ini menunjukkan bahwa aplikasi ini telah memenuhi 5 aspek usabilitas di pertanyaan 3 dan $6 . \quad$ Kemudahan menemukan halaman itinerary pada pertanyaan 5 mendapatkan nilai 4,32 dari skala 5. Nilai 4,32 ini menunjukkan bahwa aplikasi yang dibuat telah memenuhi aspek learnability dan efficiency.

\section{SIMPULAN}

Telah berhasil dibangun aplikasi mobile berbasis android terkait etourism untuk pariwisata di Bali. Pengujian usabilitas menunjukkan bahwa aplikasi tripplanner ini telah memenuhi aspek learnability, efficiency, memorability, errors dan satisfaction. Hal ini ditunjukkan dari hasil yang diperoleh pada tabel 8 rekap nilai usabilitas, dengan perolehan diatas nilai 3 (nilai tengah) dari setiap pertanyaan yang diajukan ke user.

\section{REFERENSI}

[1] D. Buhalis and S. H. Jun, "ETourism," Contemp. Tour. Rev., pp. 1-38, 2011.

[2] L. Sebastia, I. Garcia, E. Onaindia, and C. Guzman, "e-Tourism: A tourist recommendation and planning application," Proc. - Int. Conf. Tools with Artif. Intell. ICTAI, vol. 2, pp. 8996, 2008.

[3] A. A. Niknafs, "A Case-Based Reasoning Approach in E-Tourism: Tour Itinerary Planning Mohammad Ebrahim Shiri ** Mohammad Masoud Javidi ***," pp. 1-5, 2003.
[4] A. Smirnov, A. Kashevnik, A. Ponomarev, M. Shchekotov, and K. Kulakov, "Application for e-Tourism: Intelligent Mobile Tourist Guide," Proc. - 2015 IIAl 4th Int. Congr. Adv. Appl. Informatics, IIAI-AAI 2015, pp. 40-45, 2015.

[5] C. Chung-Hua and $H$. Chenyang, "A Platform for Travel Planning by Using Google Maps," 2015 16th IEEE Int. Conf. Mob. Data Manag., pp. 120 125, 2015.

[6] R. Yunus, NILAI-NILAI KEARIFAN LOKAL (LOCAL GENIUS) SEBAGAI PENGUAT KARAKTER BANGSA Studi Empiris Tentang Huyula. 2014.

[7] J. Nielsen, "Usability 101: Introduction to Usability," 2012. [Online]. Available: https://www.nngroup.com/articles/usa bility-101-introduction-to-usability/.

[Accessed: 14-Jul-2017].

[8] J. Nielsen, "Usability Engineering," Morgan Kaufmann Pietquin $O$ Beaufort $R$, vol. 44, no. 1/2002, p. 362, 1993.

[9] J. Nielsen, Usability Engineering, vol. 44, no. 3. 1993.

[10] a Holzinger, "Usability engineering methods for software developers," Commun. ACM, vol. 48, no. 1, pp. 71-74, 2005.

[11] S. Wignjosoebroto, A. Sudiarno, and D. Harenda, "PERANCANGAN INTERFACE PROTOTYPE WEB BERDASARKAN PADA ASPEK USABILITY ( Studi Kasus: Laboratorium Ergonomi dan Perancangan Sistem Kerja Teknik Industri ITS )," vol. -, no. -, pp. 1-14, 2011. 